\title{
Is the Economic Convergence of the Mexican States Possible? Estimates for the 1940-2013 Period
}

\author{
Mario Camberos C.* and Joaquín Bracamontes N.
}

\author{
Department of Economic Development at the Center for Research on Food and Development (CIAD), México
}

\begin{abstract}
In this paper we study $\beta$-convergence: absolute and conditional, also $\sigma$ convergence, using cross-state regression models, based in a long term period of time for the Federated States of Mexico. When absolute convergence is estimated (Solow Model, 1956) we found the negative sign expected but the result is not statistically reliable; while, estimates for decades only show absolute convergence for the period of 1960-1970, known with the term of "Mexican Miracle", a third regression including population growth rate and physical capital investment per capita, variables as considered by Solow models, confirm that there is not absolute convergence like the first result obtained. The estimate including human capital index $(\mathrm{HCl})$ and human development index ( $\mathrm{HDI} 2)$, shows a number of outliers, suggesting the introduction of proxy variables which capture the political effects and explore conditional convergence. When panel heteroskedastic is considerate, convergence is observed, but $\beta 2 \%$ any case was estimated.
\end{abstract}

Keywords: Convergence, human capital, regional economics.

\section{INTRODUCTION}

Mexican states low and uneven economic growth and inequality, registered last four decades, throw worries about development path, for which it is necessary to research economic growth factors that have guided failure Mexican state development. In this context it is important drive the economic convergence idea, as central subject of this paper, and review at light of our results, whether factors such as capital physic and labor, supported on Solow and human capital on Lucas models of economic growth theory, and the Barro and Sala-i-Martin hypothesis to prove Bconvergence, which has been tested for countries and regions such as the United States, the European Union using econometric methods, and new members of the European Union, explain Mexican state economic growth.

In this though line convergence hypothesis as enunciated by Lucas (1988), developed a fruitful debate that has prevailed for the last three decades, on what forces guide economic growth towards a steady state. Lucas introduced in the Cobb-Douglas functional form of production, human capital, as the most important factor on economic growth. Then Barro and Sala-i-Martin questioned whether poor countries or regions tend to grow faster than rich ones. Are there automatic forces that lead to convergence over time in the levels of per capita income and product? (Barro and Sala-i-Martin 1992). Decomposition is possible in 2 parts: the first one known as the absolute convergence

\footnotetext{
${ }^{*}$ Address correspondence to these authors at the Department of Economic Development at the Center for Research on Food and Development (CIAD), México; Tel: $6622-892400$ ext. 319; Fax: 6622-800057;

E-mail: mcamberos@ciad.mx, joaco@ciad.mx

Thanks Christian Millan and Abel Castro.
}

hypothesis or beta convergence $(\beta)$; the second part is related with conditional convergence. Both Lucas, and Barro and Sala-i-Martin insight is related to the foundation of the Endogenous Economic Growth Modern Theory.

B convergence implies that developing countries grow faster than rich ones steadily to an estimated rate of $2 \%$. (Barro and Sala-i-Martin 1992). Conditional convergence relates convergence towards different steady states. Implies that different countries achieve different income levels while in a steady state.

Another basic concept is sigma convergence $(\sigma)$, suggested by Barro and Sala-i-Martin (1992), and it is defined as income dispersion reduction during convergence period; not always observed through the process. This kind of convergence (as suggested by Barro and Sala-i-Martin 1992) is very important in the Mexican case study, which is the objective of this paper, because economic differences of development levels among regions and states have been persistent along its modern economic history; moreover, the Mexican case has been recognized in the world by its economic and social inequality, and requires a long term research with solid statistics foundations. In this paper convergence $\sigma$ is estimated.

The major factors that join to the economic growth process are capital and work (Solow, 1956), also known as the exogenous growth model, with free access to technology; population growth rate, human capital and depreciation rate (Lucas 1988; Barro and Sala-i-Martin 1992) also known as the endogenous growth model, this because the human capital makes the difference. Beta conditional regards other factors 
such as economic policies, openness, money exchange, savings, life expectancy, foreign inversion, financial dependency and government consumption (Sachs 1996; Rodrik 2014; Dobrinsky and Havlik 2014) regarding state intervention in order to achieve speed of convergence.

All models are mainly based on Cobb-Douglas function and econometric methods; Ordinary Least Squares cross-section and panel data are used to measure convergence, which will be described in the methodology section and when doing its application.

Hypothesis has been tested for counties and states in the United States (Barro and Sala-i-Martin 1992; Sachs and Warner 1996; Rodrik 2014), European Union (Dobrinsky and Havlik 2014; Dvorokova 2014); OECD (Arnold, et al. 2010); New European Union members (Sikic 2013; Oblath et al. 2015); World regions (Sala-i-Martin 1995; Mathur, 2005); counties in America (Young et al. 2008); Mexican case (DiazBautista 2000).

Hypotheses that have been proved include specific subjects too, such as public policies (Sachs and Warner 1996); infrastructure investment (Button 1998); education role (Diaz-Bautista 2000); agricultural sector (Somasekharan 2011).

In this scheme the objective is to search Bconvergence, and $\sigma$-convergence over specific regions in Mexico's federated states in a long term fashion.

The next step in this paper's strategy is to show convergence evidences for U.S country and states, EU and new members, next make a discussion about the convergence basic theory foundation and methodological approach, after showing some stylized facts on Mexico's federated states during the last 70 years, followed by analysis results and conclusions at last.

\section{CONVERGENCE HYPOTHESIS EVIDENCE}

Barro and Sala-i-Martin (1992) estimates found absolute convergence for the $1880-1988$ period, $\beta=$ 0.0175 , and for any nine period $\beta$ values interval [0.0119-0.0.0373], correct sign, value significance statistic and errors below 5\%, except 1920-1930 decade $\beta=-0.0122$ value meaning divergence. When other explicative variables are included (9 economic sectors) model estimates are mixes: before 1920-30 decades, divergence is observed, and convergence on later decades. Authors argument that this unstable pattern of $\beta$ across periods can reflect aggregate disturbances that have differential effects on state income as represented by term $\phi_{i} S_{t}$ that catch sectorial composition.

Estimation of convergence for 98 counties using the same methods, income rate annual as dependent variable, and growth per capita income, Barro and Sala-i-Martin do not find convergence $\beta$. Then several proxy variables are added to human and political capital and measure of market distortion, and conditional convergence is estimated $\beta=0.0184$, no longer below US state estimation $\beta=0.0236$ same time period 1960-1985. One of the most important conclusions found is that $\beta$-convergence around $2 \%$, became a convergence pattern and it is considered for further research in the next 25 years.

Later another authors applied the same model to estimate convergence conditional to test economic policies and politics facts impact. In this though stream, Sachs (1995) lying augment: Economic growth and therefore economic convergence require reasonably economic institutions. Poorly managed economies are unlike experience convergence no matter what the underlying production technology or initial level of human capital. Economies that are poorly managed are improbable of experimenting convergence no matter what the underlying technology or level of human capital are.

That is why as convergence condition a certain amount of dummy variables are introduced and copes with two types of countries: qualifying and nonqualifying. Non-Qualifying if one of the next features is present: 1) a socialist economic structure; 2) civil war o major external war during the period 1970-1989 and 3) extreme deprivation of civil or political rights, or do not pass the test of openness (market).

Under this criterion 81 countries were excluded of a total of 117, Latin America as a whole, Mexico due to black market's $20 \%$ premiums and due to government's domestic protection policies. The regression considers this division and parameter $B$ is estimated in a separated way.

The author test convergence hypothesis 1970-1989, initially with only income showing the simple bivariate relationship between initial income in 1970 and subsequent growth between 1970 and 1989, but does not registers convergence for the entire sample and coefficient is positive and is statistically insignificant; separating both samples, qualifying countries show 
convergence, but non-qualifying do not (results are statistically insignificant). Then 5 politics are included using 5 dummies. Results confirm the effectiveness of politics on convergence. Signs are negative, which contributes to reduce income difference between countries through time. On the other hand, Young et al. (2008) estimated convergence for the United States and 32 states, based on 3058 counties information between the 1970-1998 period, using OLS and 3SLS and getting contrasting results. So OLS estimate for USA gives $\beta=0.0239$ value and wide states interval [0.0044 West Virginia, -0.08 Idaho]; while using 3SLS $\beta$ $=0.0658$ value and states interval [California 0.0375, Louisiana 0.015]

Authors as Dvorokova (2014) used the ordinary least square test to measure absolute convergence in the period from 2001-2012 of the European Union and estimated $\beta=0.027$ and by specification model, coefficient has a negative sign, as outcome convergence was observed. In this framework analysis, Dobrinsky and Havly (2014) found in a study for 27 European Union Countries and ten new members, using an univariate and multivariate cross-country regression model of per capita income growth as dependent variable, that the 27 European economies throughout the last 35 years (ending 2012) estimates $\beta$ $=2 \%$ value convergence, similar Barro and Sala-iMartin (1992) finding twenty year ago.

Results of $\sigma$-divergence were found by Barro and Sala-i-Martin for the United States: increasing 18801930, divergence; decreasing 1930-1970, convergence and soaring 1970-1988, divergence; when sectorial composition variables are included, income dispersion of the 1930 and 1988 peak years eases up (Young et al., 2008) estimating sigma during 1970-1998, but found divergence. The 1998 standard deviation for full sample grew about 5.8 percent; meanwhile for 24 states sigma was higher at 10 percent level. Conclusion is that for many individual states as well as for the entire U.S. $\sigma$-divergence occurred from 1970 to 1998, similar to Barro and Sala-i-Martin as stated above.

\section{THEORY AND CONCEPTUALIZATION}

The standard convergence theory is based on the neoclassical concept of long-term economic growth (Dvorokova, 2014), that proposes two problems to solve: 1. Solovian (Solow, 1955) per capita income growth to constant rate in the long term assuming capital free access, labor and another external factors integrated in the Cobb-Douglas production function, included Solow residual, and known as Exogenous Development Model and 2. Lucasian (Lucas, 1988) and his concern to include some endogenous factors such as human capital and technological innovation, like development foundation.

Both Solow and Lucas models are basic for Barro and Sala-i-Martin (1992) convergence theory that guarantees that the economic growth in developing countries, will be faster than in rich countries in long term. Considering as an outset different neoclassicals as Ramsey (1925) and Solow (1956), per capita growth rate tends to be inversely related to initial production or income per person. Particularly, if economies are similar according to preferences and technology, then the poor economies grow faster than rich ones. Thus there is a force that promotes convergence in levels of per capita product and income, as outlined by Barro and Sala-i-Martin. So speed growth poorer countries, or regions, in combination with slow growth richer countries outcome convergence in the long run toward steady state, defined a situation that guarantees a constant growth rate of population, capital, as consequence the income-product growth was considered as stylized facts.

It is possible to distinguish three concepts of convergence. Two $\beta$-convergence: absolute and conditional convergence, and at last, $\sigma$-convergence. Barro and Sala-i-Martin (1992) define original convergence as a process of long term growth income speed of the developing countries in comparison to the rich ones towards a steady state. According to Sikic (2013), absolute convergence assumes that the countries of analyzed groups have the same characteristics. Dvorokova (2014) argue in a recent paper for the EU, that initially poorer countries evidence more dynamic growth. This means that poorer countries converge to initially richer countries because those do not have such dynamic growth.

Conditional convergence, opposite to absolute convergence, postulates that convergence is based on endogenous factors promoted by mean economic policies such as: investment in human capital and infrastructure, in addition to capital equipment; economic liberalization and money exchange policies (Lucas 1988; Sachs 1996; Young et al. 2008; Rodrik2014), all together achieve faster convergence.

However convergence is not an ineluctable fact; by the time, dissident authors as Romer, (cited by Sachs 
1996) noted that his theoretical [Solow] model with increasing returns to scale seemed to be broadly consistent with cross-country growth experience of the postwar era, in which there was no discernible trend of poorer nation to converge with the richer nations. In the same line of thought Baumol (1994 Sachs cited) suggested that only countries with an adequate initial level of human capital endowments could take advantage of modern technology to enjoy the possibility to convergent growth.

After thirty years of discussion about convergence, several questions may arise from this initial observation 1. What growth rate guarantees convergence to steady state? 2. Does Convergence guarantees income dispersion reduction of the poorest in relation to the richest countries?

Barro and Sala-i-Martin model analyses questions and propose the average growth rate of $Y$ over the interval between dates 0 and $\mathrm{T}$ :

$\frac{1}{T} \cdot \log \left[\frac{Y(T)}{Y(0)}\right]=x+\frac{1-e^{-\beta T}}{T} \cdot \log \left[\frac{\hat{Y}^{*}}{\hat{Y}(0)}\right]$

Where $Y=$ income, $\hat{Y}$ =income growth rate, $\hat{Y}^{*}=$ steady state income growth rate, $\mathrm{T}=$ years, $\beta=$ parameter measure convergence rate and $X=$ progress technological exogenous.

Special interest represents $\beta$ parameter, in which its negative sign demonstrates if convergence really exists, and its value, growth rate, to steady state. In this point of analysis most authors refuse Solow model of convergence as a natural result of economic growth and exogenous factors, and prefer to include endogenous factors (Lucas 1988; Barro and Sala-iMartin 1992), economic and social policies (Sach1996, Rodrik 2014).

In relation to the second question, Dvorokova (2014), based on a recent European Union research, claims that it is not entirely clear that $\beta$-convergence guarantees income dispersion reduction. On the other hand, Young et al. (2008) claims that despite literature emphasizes on $\beta$-convergence, economists have acknowledged that is not a sufficient condition for $\sigma$ convergence. Quah and Friedman, following the author, both suggest that $\sigma$-convergence is of most interest because it directly tells whether distribution of income across economies is becoming more equitable or not; while Barro and Sala-i-Martin (1992) explain that $\beta$-convergence does not implies that the cross - sectional dispersion of log $\left(y_{i t}\right)$ decline over time. The effect of $\beta$-convergence, which tends to reduce dispersion, is balanced by random shocks, which tend to increase this dispersion.

Authors demonstrate by means of this formulation:

$\sigma_{t}^{2}=\left(e^{-2 \beta}\right) \sigma_{t-1}^{2}+\sigma_{\mu}^{2}$

$\sigma_{t}^{2}=\frac{\sigma_{\mu}^{2}}{1-e^{-2 \beta}}+\left(\sigma_{0}^{2}-\frac{\sigma_{\mu}^{2}}{1-e^{-2 \beta}}\right) e^{-2 \beta}$

As it is observed in both equations $\sigma_{t}^{2}$ monotonically approaches the steady state value, which rises with $\sigma_{\mu}^{2}$ but decline with $\beta$.

Sigma convergence has been converted now day in important subject, regarded as one of relevant problems because the inequality has reached high levels within, as between world countries, in consequence, is very important to search Mexican states case sigma convergence too.

\section{METHODOLOGY AND DATA}

In this part, steps to measure $\beta$ and $\sigma$ convergence will be explained. Econometric methods have been used to operate the economic growth and per capita income relation to measure convergence, principal cross-section, pooled and panel models.

\section{1. $B$ and $\sigma$ Convergence}

Dvorokova (2014) found out that the methodology to measure $\beta$-convergence, comes from original Baumol (1986) real convergence study; but Barro and Sala-iMartin (1992) elaborated an equation that became the standard one using a cross-section country method to estimate $\beta$-absolute convergence:

$\log \left(y_{i t} / y_{i, t-1}\right)=a-\left(1-e^{-\beta}\right) \cdot \log \left(y_{i, t-1}\right)+\mu_{i, t}$

Where per capita real GDP is used, $t$ represents the time (in years), $i$ represent the nation or region and $\mu$ stochastic error term. The left-hand side is the growth in per capita income and explanatory variable on the right-hand side is the initial period per capita income, $a$ and $\beta$ coefficients are estimated by no lineal least squares techniques. If $\beta$ is estimate positive convergence is implied (negative exponent). A larger $\beta$ represents faster convergence (Pfitzner and Lang, 2014). 
Conditional convergence is measured, following Ling, et al., (2003) using a model that includes a number of other variables In order to keep the steady state characteristics of economics constant:

$\frac{1}{T} \ln \frac{y_{i, t}}{y_{i, t}-T}=\alpha-\frac{1-e^{-\beta T}}{T} \ln y_{i, t}+\phi X_{i, t}+u_{i t}$

The dependent variable is the average rate of growth for a country $i, T$ is interval of years, $X_{i, t}$ is a set of exogenous variables maintaining the steady state characteristics and $\phi$ is a set of unknown coefficients. To operate model econometric and estimate $\beta$ convergence Barro and Sala-i-Martin (1992) used a cross-state regression model, assuming that the coefficient $a$, is the same for all $i$; they assume that the steady state value, $\hat{y}_{i}^{*}$ (equation 1 , above) and the rate of technological progress, $x_{i}$, do not differ across states.

However, it includes variables which they think could hold the effects of aggregate shocks on economy i's growth rate to achieve cross-sectional independence of error terms $v_{i t}$ in equation $u_{i t}=\phi_{i} s_{t}+v_{i t} \quad\left(s_{\mathrm{t}}\right.$ is used by Barro and Sala-i-Martin 1992).

Sigma convergence has been measured by mean standard deviation as the simple variance of log income on $t$ time (Young et al., 2008):

$\sigma_{t}^{2}=\left(\frac{1}{N}\right) \sum_{i=1}^{N}\left[\ln \left(y_{i t}\right)-\mu_{t}\right]^{2}$

\subsection{Econometric Model to Prove Mexican States B- Convergence}

To operate the econometric model and estimate $\beta$ convergence using a cross-state regression is used. It is necessary to prove both, exogenous and endogenous models according to the next proceeding:

1). general model of convergence, following Barro and Sala-i-Martin (1992) and Dvorokova (2014):

$\frac{1}{T} \log \left[\frac{y_{i, t}}{y_{i, 0}}\right]=\alpha+\beta \log \left(y_{i, 0}\right)+\varepsilon_{i}$

Where $\beta$ parameter to measure convergence, $\alpha$ is a constant parameter, $\varepsilon i$ is the index of the Mexican states (32 states registered for this paper), 0 and $T$ are the indexes for the time $(0=1960, T=2013)$.

2). Convergence exogenous as Solow Model:
$\frac{1}{T} \ln \frac{y_{i, t}}{y_{i, t-T}}=\alpha-\frac{1-e^{-\beta T}}{T} \cdot \ln y_{i, t-T}+\phi X_{i, t}+u_{i t}$

With variables defined as (5), added $X_{i, t}$, that include a group of 2 new variables: $k$ (capitalper capita) and $n$ (population growth rate). 3). Convergence endogenous model like Lucas Model, that add to (7), a group of variables $Z_{i, t}$ definited as:

$\frac{1}{T} \ln \frac{y_{i, t}}{y_{i, t-T}}=\alpha-\frac{1-e^{-\beta T}}{T} \cdot \ln y_{i, t}+\phi X_{i, t}+\theta Z_{i, t}+u_{i t}$

New variables defined as I (labor returns originating from human capital) and $\mathrm{h}$ (human capital index composed of education and health.

In this paper is assumed, as Barro and Sala-i-Martin (1992), that the coefficient $\alpha$ is the same for all $\mathrm{i}$; that is, they assume that the steady-state value, $\hat{y}_{i}^{*}$ (equation 1) and the rate of technological progress do not differ across Mexican states. This model is regulated through OLS regression cross-sectional data of the states and the hypothesis is tested by using the Bayesian information method.

Sigma convergence is measured with standard deviation $\sigma$ as in (6). Finally speed convergence is estimated by using the following formula:

$T=\ln (2) / \beta$

Where variables are defined as above.

\subsection{Data}

Table 1 shows some indicators and index that describes the growth and development in Mexico for the 1940-2013 period, specifically the annual average rates of population growth, GDP per capita and capital formation, the human capital index $(\mathrm{HCl})$ and the human development index (HDI 2). These growth rates and development index were estimated from the databases devised and constructed in the effort to obtain homogeneous and comparable statistics series over time of the states in Mexico in order to facilitate long-term studies on issues such as economic growth, regional inequality, convergence, etc. (German-Soto 2005; German-Soto 2008;German-Soto et al. 2013).

\section{THE STYLIZED FACTS}

The growth rates of GDP per capita help to identify two stages on the path of economic growth in the country. The first stage comprises boom era and the 
Table 1: Mexico. Economic Development Statistics 1940-2013

\begin{tabular}{|c|c|c|c|c|c|c|c|}
\hline & 1940-1950 & 1950-1960 & $1960-1970$ & $1970-1980$ & $1980-1990$ & $1990-2000$ & 2000-2013 \\
\hline Growth Rate Population & 2.41 & 2.76 & 3.06 & 2.88 & 1.81 & 1.79 & 1.51 \\
\hline Growth Rate GDP/Percápita & 2.81 & 2.72 & 2.93 & 2.78 & -0.58 & 0.71 & 0.71 \\
\hline GDP/Percápita ${ }^{1}$ & $4,671.7$ & $6,226.5$ & $8,353.0$ & $11,259.0$ & $13,427.3$ & $13,436.2$ & $22,067.2$ \\
\hline Growth Rate Stock/Percápita & nd & nd & 4.91 & 4.61 & 8.78 & -0.86 & 0.12 \\
\hline Stock/Percápita ${ }^{1}$ & nd & nd & $11,491.7$ & $19,815.5$ & $48,686.9$ & $74,545.1$ & $63,252.2$ \\
\hline Labor-Income and $\mathrm{HCl}$ & nd & 3.52 & 2.75 & 3.67 & 4.52 & 6.69 & 8.56 \\
\hline HDI(2) & nd & 0.582 & 0.655 & 0.739 & 0.811 & 0.867 & 0.883 \\
\hline
\end{tabular}

Both amounts are in Mexican pesos, based 1993.

Source. Own estimates based on:

1. Germán-Soto, Vicente (2005): "Generación del producto interno bruto mexicano por entidad federativa, 1940-1992", El Trimestre Económico, vol. 72(3): 617-653.

2. Germán-Soto, Vicente (2008): "El stock de capital industrial medido a través de la relación inversión-empleo: estimaciones para los estados mexicanos",

Ensayos, 27(1): 53-80.

3. German-Soto, Vicente; Reyna E. Rodríguez Pérez and Carmen N. Escamilla Jiménez. 2013."Acumulación y desigualdad del capital humano entre los estados mexicanos durante 1960-2008”, Paradigma Económico, Revista de Economía Regional y Sectorial, 5(2): 5-31.

4. Germán-Soto, Vicente (2015): "Population Statistics by Mexican federal entity", from the Selected Works of Vicente German-Soto.

process of import substitution industrialization (Blanco 1979 and Huerta 1986), which covers the first three decades (1940-1970), where the economic growth remains at relatively low rates: $2.81 \%, 2.72 \%$ and $2.93 \%$, which are lower than the rate of population growth.

The second stage includes the last four periods of analysis (1970-2013), which comprises for a significant drop in the rate of national economic growth. In this way, we can see that in the decade of the 1970's the average GDP per capita annual growth rate resulted in $2.78 \%$-less than population growth rate-, despite the inequality in the balance of payments (BOP), the public deficit and price increases that forced the Mexican peso devaluation of the peso in August of 1976 (Ros 1987 and Huerta 1986).

For the decade of the 1980's, in the context of the crisis and renegotiation of the foreign debt, it can be seen an abrupt drop of economic growth in the country due to a negative rate of $-0.58 \%$ recorded over this period, while the average annual population growth was $1.81 \%$, whereby this period has been named the lost decade of economic dynamics in Mexico.

In the decade of the 1990's economic growth rate was only of $0.71 \%$, in a context of current account deficit due to the high inflow of capital invested in shortterm financial instruments rather than productive investment (Guillén 2000), which led to the devaluation of December $29^{\text {th }}$, 1994, which in turn became in inflation and economic stagnation. Similarly, in the global financial crisis of the century, the economic growth rate was just $0.71 \%$ in the Mexican economy, while the average annual growth rate of population was $1.51 \%$.

Despite a steady increase seen on the national GDP per capita, the trend observed in the average rates of economic growth per decade do not realize that the country was holding a process of economic convergence, a situation confirmed by analyzing the behavior growth rates in the enclosed states, particularly those states that have historically been the most underdeveloped states in the Mexican economy: Chiapas, Guerrero and Oaxaca, which for the last period of analysis showed growth rates of $-0.14 \%$, $0.26 \%$ and $0.67 \%$, respectively. Moreover, all states experienced a drop in the growth rate of GDP per capita throughout the study period, as same as the country itself (see Table 2).

In terms of capital stock per capita accumulated a continuous increase over the period is also observed, but when analyzing the mean annual growth rates of capital stock per capita a process of less capitalization of the Mexican economy in long term can be seen, which shows a process of divergence rather than economic convergence in the country. The apparent contradiction between the high rate of growth in stock per capita and the sharp drop in the growth rate observed in the eighties, is explained by the high inflow of capital invested in short-term financial instruments rather than productive investment, which led to the crisis of mid-1990's.

On the other hand, human capital index based on labor income (Labor-Income based $\mathrm{HCl}$ ) measures the skills and abilities of people who are involved in 
Table 2: Mexico. Economic Development Statistics for States 1940-2013

\begin{tabular}{|c|c|c|c|c|c|c|c|c|c|c|c|}
\hline States & $\begin{array}{c}\text { Population } \\
1940\end{array}$ & $\begin{array}{c}\text { Population } \\
2013\end{array}$ & $\begin{array}{c}\text { Growth } \\
\text { Rate } \\
\text { Population } \\
\text { 1940-2013 }\end{array}$ & $\begin{array}{c}\text { GDP/ } \\
\text { Per } \\
\text { capita }^{1} \\
1940\end{array}$ & $\begin{array}{l}\text { GDP/ } \\
\text { Per } \\
\text { capita }^{1} \\
2013\end{array}$ & $\begin{array}{c}\text { Growth } \\
\text { Rate } \\
\text { GDP/ } \\
\text { Per } \\
\text { capita } \\
1940- \\
2013\end{array}$ & $\begin{array}{c}\text { Capital/ } \\
\text { Per } \\
\text { capita }{ }^{1} \\
1960\end{array}$ & $\begin{array}{l}\text { Capital/ } \\
\text { Per } \\
\text { capita }^{1} \\
2013\end{array}$ & $\begin{array}{c}\text { Growth } \\
\text { Rate } \\
\text { Stock } \\
\text { K PC } \\
1960- \\
2013\end{array}$ & $\begin{array}{c}\text { Labor- } \\
\text { incomebased } \\
\text { IHC (2008) }\end{array}$ & $\begin{array}{l}\text { Combined } \\
\text { index of } \\
\text { Education } \\
\text { and } \\
\text { Health } \\
(2008)\end{array}$ \\
\hline Aguascalientes & 161,693 & $1,252,265$ & 2.80 & $4,135.3$ & $22,512.3$ & 2.32 & $2,441.0$ & $89,454.2$ & 6.90 & 8.396 & 0.898 \\
\hline Baja California & 78,907 & $3,381,080$ & 5.21 & $16,392.5$ & $18,247.5$ & 0.14 & $10,848.3$ & $53,308.8$ & 2.99 & 7.741 & 0.905 \\
\hline $\begin{array}{c}\text { Baja California } \\
\text { Sur }\end{array}$ & 51,471 & 718,196 & 3.63 & $3,782.9$ & $17,838.7$ & 2.12 & $5,364.5$ & $41,413.7$ & 3.86 & 7.600 & 0.904 \\
\hline Campeche & 90,460 & 880,299 & 3.12 & $3,443.6$ & $15,247.5$ & 2.03 & $11,760.4$ & $290,962.5$ & 6.12 & 20.202 & 0.878 \\
\hline Coahuila & 550,717 & $2,890,108$ & 2.27 & $6,083.5$ & $23,706.3$ & 1.86 & $11,544.0$ & $157,994.6$ & 4.96 & 8.564 & 0.897 \\
\hline Colima & 78,806 & 698,295 & 2.99 & $5,072.7$ & $15,862.2$ & 1.55 & $3,190.2$ & $70,650.3$ & 5.90 & 6.382 & 0.892 \\
\hline Chiapas & 679,885 & $5,119,186$ & 2.77 & $1,532.5$ & $6,292.0$ & 1.93 & 339.6 & $12,391.3$ & 6.89 & 10.059 & 0.834 \\
\hline Chihuahua & 623,944 & $3,635,966$ & 2.41 & $4,626.0$ & $24,278.1$ & 2.27 & $9,822.9$ & $55,086.9$ & 3.24 & 8.043 & 0.898 \\
\hline Distrito Federal & $1,757,530$ & $8,893,742$ & 2.22 & $14,684.1$ & $44,625.4$ & 1.51 & $19,652.8$ & $73,597.2$ & 2.48 & 9.417 & 0.911 \\
\hline Durango & 483,829 & $1,728,429$ & 1.74 & $5,526.5$ & $14,717.3$ & 1.33 & $5,197.6$ & $41,096.8$ & 3.90 & 5.962 & 0.887 \\
\hline Guanajuato & $1,046,490$ & $5,719,709$ & 2.32 & $1,901.0$ & $13,453.0$ & 2.68 & $2,653.7$ & $32,587.6$ & 4.75 & 6.348 & 0.880 \\
\hline Guerrero & 732,910 & $3,523,858$ & 2.14 & $1,289.9$ & $8,124.9$ & 2.52 & $1,140.1$ & $49,876.0$ & 7.25 & 4.695 & 0.837 \\
\hline Hidalgo & 771,818 & $2,806,334$ & 1.76 & $1,968.1$ & $9,365.9$ & 2.13 & $5,012.2$ & $90,199.5$ & 5.50 & 7.962 & 0.874 \\
\hline Jalisco & $1,418,310$ & $7,742,303$ & 2.32 & $2,472.2$ & $15,925.2$ & 2.55 & $7,425.7$ & $57,340.9$ & 3.86 & 7.533 & 0.892 \\
\hline México & $1,146,034$ & $16,364,210$ & 3.66 & $1,887.4$ & $13,080.2$ & 2.65 & $21,039.9$ & $45,705.7$ & 1.45 & 8.875 & 0.899 \\
\hline Michoacán & $1,182,003$ & $4,529,914$ & 1.83 & $1,437.3$ & $9,411.7$ & 2.57 & $3,326.3$ & $30,466.2$ & 4.19 & 5.588 & 0.866 \\
\hline Morelos & 182,711 & $1,874,188$ & 3.20 & $3,267.4$ & $15,304.9$ & 2.11 & $4,299.5$ & $20,923.2$ & 2.97 & 8.522 & 0.892 \\
\hline Nayarit & 216,698 & $1,178,403$ & 2.31 & $2,562.6$ & $9,431.8$ & 1.78 & $1,708.7$ & $47,267.9$ & 6.34 & 5.837 & 0.886 \\
\hline Nuevo León & 541,147 & $4,941,059$ & 3.03 & $6,645.5$ & $31,341.6$ & 2.12 & $40,064.0$ & $168,274.1$ & 2.69 & 9.012 & 0.903 \\
\hline Oaxaca & $1,192,794$ & $3,959,042$ & 1.63 & 808.8 & $6,980.4$ & 2.96 & 671.8 & $16,774.3$ & 6.14 & 9.352 & 0.847 \\
\hline Puebla & $1,294,620$ & $6,067,607$ & 2.11 & $1,584.3$ & $11,597.1$ & 2.73 & $7,507.5$ & $59,119.6$ & 3.90 & 7.419 & 0.871 \\
\hline Querétaro & 244,737 & $1,943,889$ & 2.84 & $4,424.2$ & $20,960.5$ & 2.12 & $5,045.7$ & $102,006.2$ & 5.73 & 8.774 & 0.889 \\
\hline Quintana Roo & 18,752 & $1,484,960$ & 6.09 & $7,897.7$ & $22,315.8$ & 1.41 & 917.5 & $10,407.4$ & 4.60 & 8.156 & 0.900 \\
\hline San Luis Potosí & 678,779 & $2,702,145$ & 1.88 & $2,171.9$ & $14,310.2$ & 2.58 & $2,635.8$ & $44,149.4$ & 5.36 & 7.970 & 0.883 \\
\hline Sinaloa & 492,821 & $2,932,313$ & 2.44 & $3,693.3$ & $13,395.0$ & 1.76 & $6,330.0$ & $26,892.3$ & 2.71 & 6.500 & 0.887 \\
\hline Sonora & 364,176 & $2,851,462$ & 2.82 & $5,165.5$ & $22,061.9$ & 1.98 & $6,014.4$ & $48,497.6$ & 3.94 & 7.705 & 0.899 \\
\hline Tabasco & 285,630 & $2,334,493$ & 2.88 & $2,543.7$ & $10,155.0$ & 1.89 & 936.6 & $211,137.1$ & 10.55 & 22.407 & 0.880 \\
\hline Tamaulipas & 458,832 & $3,461,336$ & 2.77 & $6,029.4$ & $17,077.9$ & 1.42 & $5,465.9$ & $60,706.5$ & 4.56 & 8.923 & 0.895 \\
\hline Tlaxcala & 224,063 & $1,242,734$ & 2.34 & $1,724.0$ & $8,235.0$ & 2.14 & $4,910.2$ & $43,506.6$ & 4.12 & 5.646 & 0.898 \\
\hline Veracruz & $1,619,338$ & $7,923,198$ & 2.17 & $3,533.3$ & $10,137.8$ & 1.43 & $8,426.8$ & $88,520.9$ & 4.45 & 13.826 & 0.859 \\
\hline Yucatán & 418,210 & $2,064,151$ & 2.18 & $4,411.1$ & $13,496.3$ & 1.52 & $8,464.1$ & $32,425.1$ & 2.52 & 4.877 & 0.879 \\
\hline Zacatecas & 565,437 & $1,550,179$ & 1.37 & $1,718.8$ & $11,555.7$ & 2.61 & $2,742.2$ & $52,022.5$ & 5.60 & 7.301 & 0.892 \\
\hline National & $19,653,552$ & $118,395,054$ & 2.46 & $3,919.8$ & $16,697.6$ & 1.98 & $9,200.7$ & $63,569.4$ & 3.64 & 8.556 & 0.883 \\
\hline
\end{tabular}

${ }^{1}$ Both amounts are in Mexican pesos, based 1993.

Source. Own estimates based on:

1. Germán-Soto, Vicente (2005): "Generación del producto interno bruto mexicano por entidad federativa, 1940-1992", El Trimestre Económico, vol. 72(3): 617-653.

2. Germán-Soto, Vicente (2008): "El stock de capital industrial medido a través de la relación inversión-empleo: estimaciones para los estados mexicanos", Ensayos, 27(1): 53-80.

3. German-Soto, Vicente; Reyna E. Rodríguez Pérez and Carmen N. Escamilla Jiménez. 2013."Acumulación y desigualdad del capital humano entre los estados mexicanos durante 1960-2008", Paradigma Económico, Revista de Economía Regional y Sectorial, 5(2): 5-31.

4. Germán-Soto, Vicente (2015): "Population Statistics by Mexican federal entity", from the Selected Works of Vicente German-Soto.

production, generating income for themselves and the economy as a whole (IMF 2015). In other words, the
$\mathrm{HCl}$ allows quantifying progress in human capital performance and includes many of the productive 
aspects of the human being, to the extent in which they are incorporated in the wages of workers (GermanSoto et al. 2008). For example, job training or experience contribute to human capital, the more these characteristics are incorporated into wages, more easily they are captured by Labor-Income based $\mathrm{HCl}$.

Henceforward, the analysis shows a significant improvement in performance of long term human capita in the country, as it went from a $3.52 \mathrm{HCl}$ in the early 1950 's an $\mathrm{HCl} 8.56$ for the last decade. In this regard, only nine states exceed the national long term $\mathrm{ICH}$ : Campeche, Chiapas, Mexico City, Nuevo Leon, Oaxaca, Queretaro, Tabasco, Tamaulipas and Veracruz; whereas states with the lowest $\mathrm{HCl}$ were Guerrero and Yucatan, followed by Tlaxcala, Nayarit, Michoacán, Durango, Guanajuato and Colima (see Table 2).

The basic methodology of combined education and health index (HDI 2) lay on the United Nations Development Programme (UNDP) proposal for the

Table 3: Estimates of $\beta$ and $\sigma$ Convergence for Federal States of Mexico

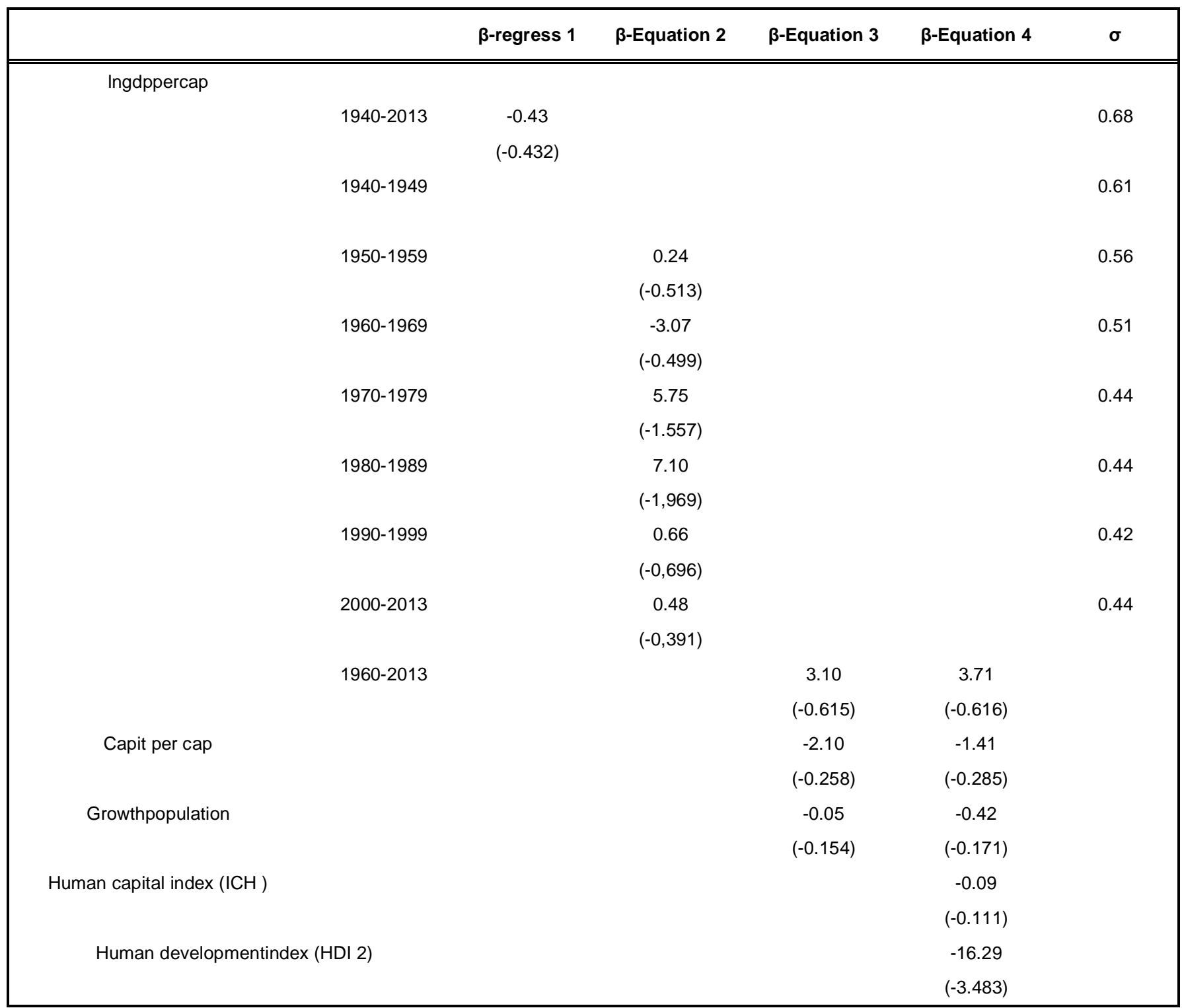

${ }^{1}$ Both amounts are in Mexican pesos, based 1993.

Source. Own estimates based on:

1. Germán-Soto, Vicente (2005): "Generación del producto interno bruto mexicano por entidad federativa, 1940-1992", El Trimestre Económico, vol. 72(3): 617-653.

2. Germán-Soto, Vicente (2008): "El stock de capital industrial medido a través de la relación inversión-empleo: estimaciones para los estados mexicanos", Ensayos, 27(1): 53-80.

3. German-Soto, Vicente; Reyna E. Rodríguez Pérez and Carmen N. Escamilla Jiménez. 2013."Acumulación y desigualdad del capital humano entre los estados mexicanos durante 1960-2008”, Paradigma Económico, Revista de Economía Regional y Sectorial, 5(2): 5-31.

4. Germán-Soto, Vicente (2015): "Population Statistics by Mexican federal entity", from the Selected Works of Vicente German-Soto. 
creation of the human development index of the countries; therefore, this index is based on the measured educational performance with the following data: a) adult literacy b) school attendance rate and life expectancy at birth as a proxy variable for health (German-Soto et al. 2013). It can be seen that in the country this measure steadily increases and does not decreases, from 0,582 in the early 1950 ' $s$ to 0.883 in the last decade.

In all the included years the Federal District stands out with the highest combined index, followed by states that are mainly located in the northern border region: Baja California, Baja California Sur, Nuevo Leon, Sonora, Coahuila and Chihuahua; while the southern states of Guerrero, Oaxaca and Chiapas are invariably classified with the lowest composite index, followed by other entities such as Hidalgo, Puebla, Michoacán (see Table 2).

\subsection{Mexican States Convergence Analysis Results}

Table 3 register all results described in this apart. Firstly relationship economic growth rate and per capita income OLS all period is analyzed. By the way, regression 1 estimate absolute convergence $B=$ 0.4901 for all period $T$, annual 0.0067 , negative sign is the expected, but standard error is higher than 5 percent. Tests $t$ and $F$ register reduced values and $\mathrm{R}^{2}$ tends zero; therefore statistic confidence is not proved.
Figure 1 confirms the findings, because is not observed any tendencies through period, but values concentration zero economic growth; even more, if statistic confidence was not considered, absolute convergence Mexican states because lower economic growth during last 73 years, which outcomes, if economic growth span is estimated as $T=\ln 2 / B=$ 0.0067 , convergence it is possible in the next 100 year, bad news for Mexican states economic growth.

A second step estimates convergence Mexican states, for any one decade using regression 2. Results, on base Table 3 , register no convergence $\beta$, except for 1960-1970 decade, by the time named Mexican economic miracle; as in this time was recognized, by media, like Mexican moment.

Finding above described are caused by states heterogeneity economic and social characteristic of Mexican development along Twenty Century: North close to U.S., which economic activity is related industrial and modern services employment and South tied to poor Central America region sustained on agricultural sectorial economic and artisanal works. In this framework economic growth states findings reflex an uneven Mexican regional development. Results perhaps evidence no operate neoclassical assuming state homogeneity, as it is observed U.S. states (Barro and Sala-i-Martin, 1992; Young et al., 2008), EU

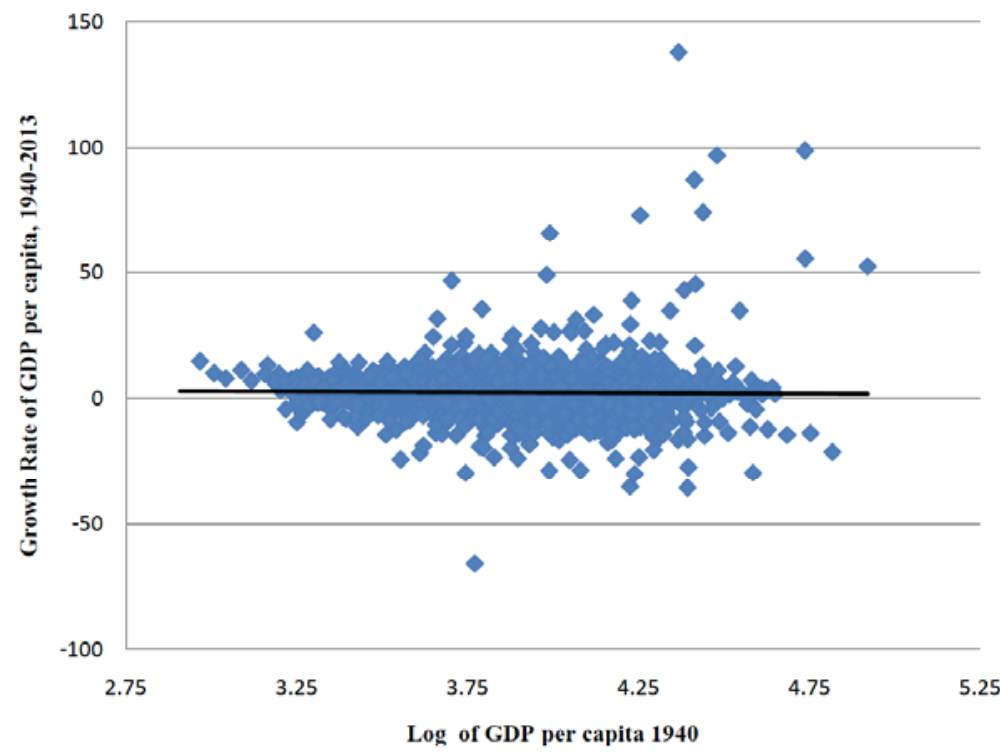

Source. Own stimates based on: 1) Germán-Soto, Vicente (2005): "Generación del producto interno bruto mexicano por entidad federativa, 1940-1992", El Trimestre Económico, vol. 72(3): 617-653; 2 )Germán-Soto, Vicente (2008): "El stock de capital industrial medido a través de la relación inversión-empleo: estimaciones para los estados mexicanos", Ensayos, 27(1): 53-80; 3 )German-Soto, Vicente; Reyna E. Rodríguez Pérez and Carmen N. Escamilla Jiménez. 2013."Acumulación y desigualdad del capital humano entre los estados mexicanos durante 1960-2008", Paradigma Económico, Revista de Economía Regional y Sectorial, 5(2): 5-31; 4 ) Germán-Soto, Vicente (2015): "Population Statistics by Mexican federal entity", from the Selected Works of Vicente German-Soto.

Figure 1: Economic Growth and GDP per capita Mexican States long term relationship. 
members (Dvorokova 2014) and Western Europe countries (Dobrinsky and Havly2014), basic for success and speed convergence process.

A third regression including population growth rate and physical capital invest per capita, variables regarded by Solow models. In this case data considerate period 1960-2013, capital stock per capita variable data is registered. In the same Table 3, Bconvergence parameter has positive sign and higher value; in this way as estimates above report divergence and seems confirm states uneven capital access as before spot lighted.

At last regression that considers labor human capital index, education and health mixed human capital index. Results reported of the other explicative variables Solow and Lucas models, register negative sign, that could mean convergence contribution; but coefficient B-convergence positive sign, say a different history, refute convergence hypothesis.

It is not interesting Bayesian test to choose better model, both Solow and Lucas do not back results. Two points is necessary take a count: 1. a lot of outliers in time series were observed; quality data should be better by dropped out. 2 . Introduce proxy variables that catching up policies effects and explore conditional convergence.

\subsubsection{Panel Analysis}

Now 32 states information is organized as panel analysis heteroskedastic: 2336 observations, 32 groups and 73 periods. Results are registered in Table 4. It show an important coefficient $\beta=-1.0461$, that mean convergence, in addition statistic confidence is good, because standard error lesser $5 \%$, as heterogeneous differences among states is eliminated by using heteroskedastic panel balanced. As outcome, convergence path $T=\ln 2 / B=0.0143=48.5$ years, is reduced at half years, related one hundred years OLS estimates; therefore, if the state heterogeneous was eliminated convergence long term is possible.

\section{2. $\sigma$-Convergence}

The 0.677 sigma value for the entire 1940-2013 period, is larger compared to the United States at its very beginning in 1940. Nevertheless, trends are similar (Table 3): decreasing between 1940-1970 as the $\sigma$ value decreased from 0.612 to 0.437 , which reflects an income dispersion markdown between the entities in Mexico. Therefore, convergence was observed, but throughout the last three decades of the $20^{\text {th }}$ century, it sustained a slight increase to $\sigma=0.441$.

$\sigma$-convergence results coincide with a Mexican economic slow growth, situation observed since 35 years ago. This is a very important finding, because convergence hypothesis does not admit this result, but it is shown in the Mexican state economic growth over the twentieth century and the beginning of the present one.

Finally is necessary, to contribute convergence, say that in comparative with our finding, Diaz-Bautista (2000) study, estimated B-convergence 1970-1993 period, model include, as explicative variable, different education levels. The study finds that the annual rate of convergence of human capital per capita in Mexico ranges from $3.55 \%$ to $4.58 \%$. It also estimates the convergence of income per capita conditional on human capital variables, but economic growth rate and per capita income relationship, as convergence hypothesis suggest, is not tasted, and so our results are not comparative at all.

\section{CONCLUSIONS}

At light of slow and uneven regional economic development registered last four decades, and worried about a new economic growth path, it is necessary to Look for factors that have guided Mexican state development. In this context central subject of this paper was to prove Mexican state B-convergence, supported on Solow and Lucas economic growth theory, and the Barro and Sala-i-Martin model to prove B-convergence hypothesis, which has been tested for countries and regions such as the United States, the

Table 4: Estimates of Panel $\beta$ Convergence for Federal States of Mexico

\begin{tabular}{|ccccc|}
\hline ecogrorate & Coef. & Std. Err. & zP>|z| & [95\% Conf. Interval] \\
\hline \hline Ingdpcap & -1.0461 & 0.1569 & -6.670 .000 & $-1.3537-.73852$ \\
cons & 11.5537 & 1.4158 & 8.160 .000 & 8.778614 .328 \\
Waldchi2(1)=44.43 & & Prob $>$ chi2 $=0.0000$ & & \\
\hline
\end{tabular}

Source: own estimates. 
European Union using econometric methods, and new members of the European Union. In the present script, Mexican states observed no convergence. Explanations are of different nature.

First, per capita income and outcome data of the economic growth dispersion showed an important aberration (outlier), which constitutes an obstacle for convergence. Second, the so-called free access to capital for developed countries does not apply for most of the states in Mexico. Capital access is more expensive, and bound to resources limitation of they both explain the observance of low levels of capital, yielding a reduced impact on the income growth per capita, and thereby, non-convergence. Third, when human capital is included, it does not support $\beta$ convergence hypothesis. The lack of sustained economic development shown over the analyzed period of time could reflect a scarce human capital resource demand. Therefore, human and physical capital does not seem to affect the economic growth. Fourth, regression panel heteroskedastic results reflex reality heterogeneous related Mexican states economic growth and it is necessary to be corrected; perhaps Government support should be considered to lead developing forces towards economic convergence.

\section{REFERENCES}

Arnold, Jens., Andrea Bassanini and Stefano Scarpetta. 2010. "Solow or Lucas? Testing Speed of Convergence on a Panel of OECD Countries".IZA DP No. 5261.

Barro, Robert J., and Xavier Sala-i-Martin 1992. "Convergence." Journal of Political Economy 100(2):223-251. http://dx.doi.org/10.1086/261816

Blanco, José. 1979. "Génesis y Desarrollo de la Crisis en México 1962-1979". Investigación Económica. 38(150): 21-88.

Button, Kenneth. 1998. "Infraestructure Investment, Endogenous Growth and Economic Convergence." The Annals of Regional Science, (32): 145-162. http://dx.doi.org/10.1007/s001680050067

Diaz-Bautista, Alejandro. 2000. "Convergence and Economic Growth in Mexico." Frontera Norte, 13(24):85-110.

Dobrinsky, Rumen. and Peter Havlik. 2014. "Economic Convergence and Structural Change: the Role of Transition and EU Accession." Wiener Institut für Internationale Wirtschaftsvergleiche.

Dvoroková, Katerina. 2014. "Sigma Versus Beta-convergence in EU28: Do They Leand to Differente Results?", Mathematical Methods in Finance and Business Administration. Proceedings of the 1st WSEAS International Conference on Pure Mathematics (PUMA '14): Tenerife, Spain, January 1012, 2014, pp. 88-94.
German-Soto, Vicente. 2005. "Generación del Producto Interno Bruto Mexicano por Entidad Federativa, 1940-1992". El Trimestre Económico. 72(3): 617-653.

German-Soto, Vicente. 2008. "El Stock de Capital Industrial Medido a través de la Relación Inversión-Empleo: Estimaciones para los Estados Mexicanos. Ensayos. 27(1): 53-80.

German-Soto, Vicente. Reyna E. Rodríguez Pérez and Carmen N. Escamilla Jiménez. 2013. "Acumulación y Desigualdad del Capital Humano entre los Estados Mexicanos Durante 19602008," Paradigma Económico, Revista de Economía Regional y Sectorial. 5(2): 5-31.

Guillén, R. Arturo. 2000. México hacia el Siglo XXI. Crisis y Modelo Económico Alternativo. México: Plaza y Valdés EditorialUAMI.

Huerta, Arturo. 1986. Economía Mexicana más allá del Milagro. México: Instituto delnvestigaciones Económicas-Ediciones de Cultura Popular, pp. 63-100.

Lucas, Robert. 1988. "On the Mechanics of Economic Development", Jounal of Monetary. (22): 3-42.

Mathur, Somesh K. 2005. "Economic Growth \& Conditional Convergence: Its Speed for Selected Regions for 19612001”, Indian Economic Review. 40(2):185-208.

Oblath, Gábor. Éva Palócz. Dávid Popper and Ákos Valentinyi. 2015. "Economic Convergnce and Structure Change in the New Member States of the European Union", MT-DP 2015/44.

Ramsey, Frank P. 1926. "The foundations of mathematics." Proceedings of the London Mathematical Society. 2(1):338384.

http://dx.doi.org/10.1112/plms/s2-25.1.338

Rodrik, Dani. 2011. "The Future of Economic Convergence."Harvard Kennedy School Goverment. Faculty Research Working Paper Series.

Ros, Jaime. 1987. "La Economía y la Política Macroeconómica Durante el Auge Petrolero: 1978-1982" in Cordera, Rolando and Tello, Carlos (eds) El Auge Petrolero de la Euforia al Desencanto. México: UNAM, pp. 13-33.

Sachs, Jeffrey. and Andrew Warner. 1995. "Economic Convergance and Economic Policies". NBER Working Paper No. 5039, February 1995

Sikic, Luka. 2013. "Long Term Economic Convergence among Ten New Members States in the Light of the Economic Crisis". Financial Theory and Practice. 37(4):361-381. http://dx.doi.org/10.3326/fintp.37.4.2

Solow, Robert M. 1956. "The Production Function and the Theory of Capital". The Review of Economic Studies. 23(2): 101-108. http://dx.doi.org/10.2307/2296293

Somasekharan, Jayasechar. Syam Prasad. and V.P. Roy Nirmal. 2011. "Convergence Hypotesis: Some Dynamics and Explanations of Agricultural Growth across Indian States", Agricultural Economics Research Review. (24):211-216.

World Economic Forum. 2015. The Human Capital Report. Employment, Skills and Human Capital. Global Challenge Insight Report. Switzerland: World Economic Forum.

Young, Andrew; Matthew Higgins and Levy Daniel. 2008. "Sigma Convergence versus Beta Convegrence: Evidence from U.S. County-Lavel Data". Journal of Money, Credit and Bank. 40(5): 1083-1093. http://dx.doi.org/10.1111/j.1538-4616.2008.00148.x

Received on 08-03-2016

Accepted on 15-04-2016

Published on 06-05-2016

\section{DOI: http://dx.doi.org/10.6000/1929-7092.2016.05.05}

(c) 2016 Camberos and Bracamontes; Licensee Lifescience Global.

This is an open access article licensed under the terms of the Creative Commons Attribution Non-Commercial License (http://creativecommons.org/licenses/by-nc/3.0/) which permits unrestricted, non-commercial use, distribution and reproduction in any medium, provided the work is properly cited. 